\title{
Population density of the Eurasian beaver (Castor fiber L.) (Castoridae, Rodentia) in the Middle Volga of Russia
}

\author{
Alexey Andreychev
}

\begin{abstract}
Andreychev, A. 2017. Population density of the Eurasian beaver (Castor fiber L.) (Castoridae, Rodentia) in the Middle Volga of Russia. - Forestry Studies | Metsanduslikud Uurimused 67, 109-115. ISSN 1406-9954. Journal homepage: http://mi.emu.ee/ forestry.studies
\end{abstract}

\begin{abstract}
The article presents research on the population density of the Eurasian beaver in the large, medium and small rivers of the Republic of Mordovia. The population density of the beaver in the large rivers of the region varies from 0.45 to 0.62 colonies per $\mathrm{km}$ (average 0.52 ). The population density in medium rivers ranges from 0.36 to 0.48 colonies per $\mathrm{km}$ (average 0.4 ). In small rivers, population density ranges from 0.2 to 0.94 colonies per $\mathrm{km}$ (average 0.46 ). The total number of beavers in the region is about 17,000 individuals as at 2016.
\end{abstract}

Key words: Eurasian beaver, Castor fiber, density population, colonies, European Russia, Mordovia.

Author's address: Department of Zoology, Mordovian State University, Bolshevistskaya str. 68, 430005, Saransk, Republic of Mordovia, Russia; e-mail: andreychev1@ rambler.ru

\section{Introduction}

Currently, the populations of the Eurasian beaver (Castor fiber L.) are being restored or will be restored in many regions in Russia. However, scientists in different countries need to ascertain population density in different parts of the area (Halley \& Rosell, 2003). Beavers undoubtedly affect many ecosystems and knowing the state of their populations is an important task (Johnston \& Naiman, 1990; Rosell et al., 2005). In 2009-2010, there were 572,500 individuals of the Eurasian beaver in the territory of Russia (Kolesnikov et al., 2011).

In Mordovia, river beavers were released in the Mordovia State Nature Reserve by zoological expedition S.S. Turov. This was carried out from 1936 until 1940 within the framework of the programme on re-acclimatisation. In total, 34 beavers were released. The Eurasian beaver was imported from the Voronezh Game Reserve. The release into the wild was carried out in small batches. The beavers were released into forest lakes, such as the Picher$\mathrm{ki}$, the Taratinskoe, the Kocheulovo, and the Inorki. As a result, the beaver population has increased rapidly. The beavers from the lakes spread throughout the rivers - the Pushta, the Uzhovka, the Satis, and the Yuzga. By 1950, the number of the growing population was estimated at 300 individuals. In 1956, 40 beaver individuals from the Mordovian reserve were released in the Zubovo-Polyansky District to accelerate settlement in the Vad River. In 1959, there were 600 beavers and in 1964, about 1,000 individuals (Borodina, 1966; Borodina et al., 1970) in the Moksha river basin. Since 1961, beavers' dwellings have 
been built (Borodin, 1970; Andreychev \& Kuznetsov, 2012) in the Sura river basin.

Until the end of the $20^{\text {th }}$ century, beavers in the region were hunted in all possible ways. As a result, they became extinct. Beaver traps have been prohibited since 2005 when they were included in the Red Book of the region. For a long time, scientific literature included no information on the number of beavers in the region. A small resurgence in beaver trapping has occurred recently. The aim of this work is to determine the density of the Eurasian beaver population in different rivers in one of the central regions of Russia.

\section{Material and Methods}

The Republic of Mordovia is located in the centre of the European part of Russia. Its extreme points are defined by geographical coordinates $42^{\circ} 11^{\prime}-46^{\circ} 45^{\prime} \mathrm{E}$ and $53^{\circ}$ $38^{\prime}-55^{\circ} 11^{\prime} \mathrm{N}$ (Figure 1). The maximum distance from west to east is $298 \mathrm{~km}$ and the distance from north to south is 57 to $140 \mathrm{~km}$. The area of the republic is 26.2 thousand $\mathrm{km}^{2}$. Features of the geological structure of Mordovia are determined by its location in the central part of the Russian Platform and the north-western slopes of the Volga Upland. In the western part of the Republic of Mordovia, the Volga Upland reaches the Oka-Don Lowlands.

The climate of the region is moderately continental with pronounced seasons throughout the year. The influx of direct solar radiation in Mordovia varies from 5.0 in December to $58.6 \mathrm{~kJ} / \mathrm{cm}^{2}$ in June. Total radiation throughout the year is $363.8 \mathrm{~kJ} /$ $\mathrm{cm}^{2}$; the radiation balance is $92.1 \mathrm{~kJ} / \mathrm{cm}^{2}$. The average annual air temperature varies from 3.5 to $4.0^{\circ} \mathrm{C}$. The average temperature of the coldest month (January) is in the range of $-11.5 \ldots-12.3^{\circ} \mathrm{C}$. Temperature drops down to $-47^{\circ} \mathrm{C}$ occur. The average temperature of the warmest month, i.e. July, is in the range of $+18.9 \ldots+19.8^{\circ} \mathrm{C}$. Extreme temperatures in the summer reach $37^{\circ} \mathrm{C}$. The average annual precipitation in the territory of Mordovia is $480 \mathrm{~mm}$. Over the course of observation lasting many years, periods of more and less humidification were noted, ranging between the minimum and maximum values of 120-180 $\mathrm{mm}$. Distribution of precipitation across the territory is not very diverse. The average long-term value of evaporation is calculated to be in the range of 390-460 mm.

According to the research of botanists, there are more than 1,230 species of vascular plants from 495 genera and 109 families in the modern flora of Mordovia. These include 4 species of plains, 8 horsetails, 18 ferns, 3 gymnosperms, and 1,197 species of flowering plants. Herbaceous perennial and annual plants predominate. The number of species of woody forms is relatively small: trees -24 , shrubs -45 , shrubs -7 , semishrubs - 5 .

The territory of Mordovia includes coniferous broad-leaf, broad-leaf forests, shrub steppes and meadow steppes. The main forest forming species are the Scots pine (Pinus sylvestris L.), Norway spruce (Picea abies (L.) Karst), European larch (Larix decidua Mill.), English oak (Quercus robur L.), common ash (Fraxinus excelsior L.), Norway maple (Acer platanoides L.), Scots elm (Ulmus laevis Pall.), silver and pubescent birch (Betula pendula Roth., B. pubescens Ehrh.), black alder (Alnus glutinosa L.), small-leaved lime (Tilia cordata Mill.) and black poplar (Populus nigra L.).

Coniferous broad-leaf or mixed forests are located in the outwash plains and adjacent terraced complexes. These include both coniferous and broad-leaved trees. In the sands of the outwash plains, the most common are pine forests, often with some characteristics of a taiga. Broad-leaved forests are prevalent mainly in interfluvial spaces of secondary morainic and erosiondenudation plains with grey forest soils as well as in floodplain complexes.

Mordovia is located in the south-western part of the Volga River basin. $47 \%$ of the area is located in the basin of Sura and 


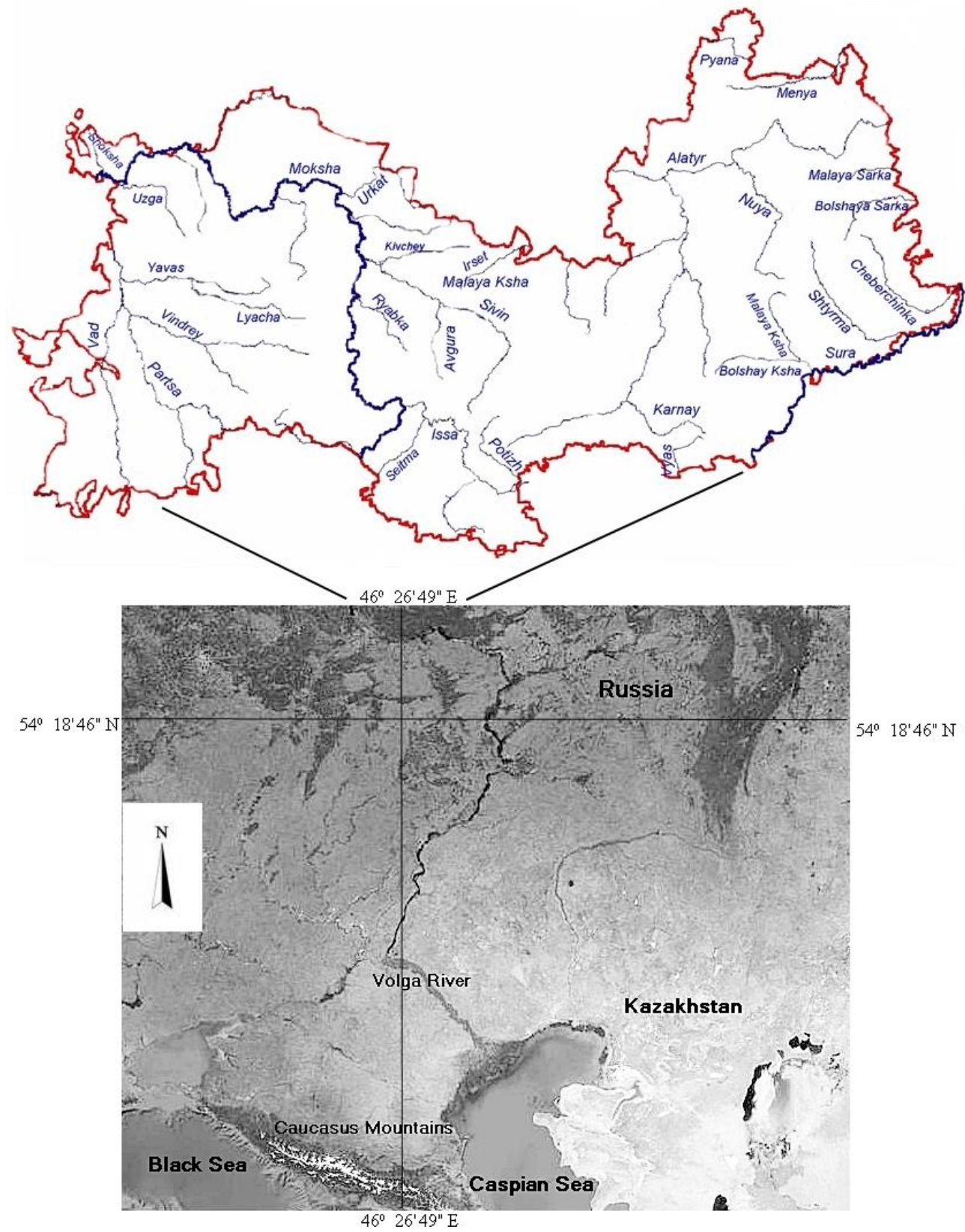

Figure 1. Geographical position of the Republic of Mordovia in Eastern Europe. 
$53 \%$ in the basin of Moksha. Moksha is the main river in western Mordovia that flows in the meridional direction to the confluence of the Urkat River, where its direction changes to the sublatitudinal. The Moksha is the right tributary of the Oka River and empties into it. The channel is $60-90$ $\mathrm{m}$ wide and 5-8 $\mathrm{m}$ deep. The absolute water level is $89-126 \mathrm{~m}$. The Moksha's largest tributaries in the territory of Mordovia are the Vad, the Satis, the Urkat, the Sivin, and the Issa.

The Sura River flows along the southeastern border of Mordovia. The width of the channel varies from 100 to $150 \mathrm{~m}$ and its depth is $10 \mathrm{~m}$. It flows $0.3-1.0 \mathrm{~m} / \mathrm{s}$ and its absolute water level is $90-115 \mathrm{~m}$. The largest tributaries of the Sura include the Bolshaya Ksha, the Bolshaya Sarka, the Piana, the Menya, and the Alatyr.

The density of the river network in the entire area is $0.23 \mathrm{~km}$ of river per $\mathrm{km}^{2}$. By the nature of intra-flow distribution, the republic's rivers are of Eastern European type. The water regime of the rivers is characterised by the presence of summer and winter seasons, spring floods and autumn floods. The most high-water month is April. $3-15 \%$ of annual runoff occurs during the low-flow period.

The river's length is used in the study as a criterion for classifying rivers. We validate this method because most reference books on surface water resources are based on that classification (Sokolov, 1964; Sokolovsky, 1968; Yevstigneyev, 1990; Chalov, 1994). According to this classification, large rivers are rivers, the length of which varies from 301 to $1,000 \mathrm{~km}$. Medium rivers are rivers with the length of 101 to $300 \mathrm{~km}$. Small rivers are rivers, the length of which ranges from 26 to $100 \mathrm{~km}$. The smallest rivers are usually the rivers with the length of up to $25 \mathrm{~km}$. In the territory of Mordovia, there are about 1,520 watercourses with the total length of $9,250 \mathrm{~km}$. The major share $(96 \%)$ of the river network of the republic falls on the smallest rivers. These constitute $65 \%$ of the total length of all rivers. Small rivers make up $4 \%$ of the total and $22 \%$ of the length of all rivers. The share of medium-sized rivers (the Issa, the Sivin, the Insar, the Partsa, the Vad, the Visha, and the Alatyr) in the total length is negligible $(0.5 \%)$. Two rivers - the Moksha and the Sura - are more than $500 \mathrm{~km}$ long (Water resources..., 1999). Small rivers and streams are distributed unevenly in the basins of large rivers. In the river Sura, there are 24 small rivers and 286 very small rivers and streams. 30 small rivers and 385 very small rivers and streams flow into the Moksha River.

It is typical for small rivers to have a 5 to $10 \mathrm{~m}$ wide channel, with extensions up to $35 \mathrm{~m}$; for average rivers, from 25 to 50 $\mathrm{m}$ with extensions up to $70 \mathrm{~m}$. Large rivers are 100 to $150 \mathrm{~m}$ wide and in the mouths, $300 \mathrm{~m}$. Rivers are shallow and the prevailing depths for small rivers is 0.4 to $1.2 \mathrm{~m}$, for average ones 1.5 to 2.0 , and for large ones 2.5 to $3.5 \mathrm{~m}$. In rundowns, the depth throughout is less than $0.5 \mathrm{~m}$. The flow rate varies from $0.2 \mathrm{~m} / \mathrm{s}$ to $1.2 \mathrm{~m} / \mathrm{s}$ in rundowns.

The studies were conducted on the rivers of Mordovia during the period of 2008-2016. The research was carried out in autumn, spring and summer due to a large amount of work. The rivers were surveyed by using the method described by Dyakov (Dyakov Yu, 1975). The number of settlements in the rivers' areas was recorded. The site of the river was selected and the number of settlements in the channel was determined. The density of individuals in the settlement was estimated by feeding activity and other traces of life activity (huts, dams, burrows). A great help in the work was provided by hunters' survey data.

Initially, enumeration was launched in 2008 in the Chermeley River in the Sura river basin (Andreychev et al., 2009). The counting station included $21 \mathrm{~km}$ from the mouth on the riverbed. Each settlement was indicated on the map by using GPS and the programme OziExplorer. This pro- 
gramme made it possible to calculate the distance between settlements, dams, and lodges, as well as calculate the area and length of the coastline.

The volume of counting work covered $468 \mathrm{~km}$ of large rivers, $558 \mathrm{~km}$ of mediumsized rivers, and 1,269 $\mathrm{km}$ of small and very small rivers. Statistical analysis was performed in MS Excel and PAST (Hammer et al., 2001).

\section{Results}

The population density of the Eurasian beaver in large rivers in the region ranges from 0.45 to 0.62 colonies per $\mathrm{km}$ (average 0.52 ) (Figure 2). The population density in medium rivers varies from 0.36 to 0.48 colonies per $\mathrm{km}$ (average 0.4 ). In small rivers, population density ranges from 0.2 to 0.94 colonies per $\mathrm{km}$ (average 0.46) (Sosnina et al., 2014). Thus, the average density of the beaver in large and small rivers is higher than in average rivers. However, the density of the Eurasian beaver population in small rivers is ambiguous. They can be divided into three groups: those with a low population density (less than 0.3 colonies/ $\mathrm{km}$ ), average density (from 0.3 to 0.5 colonies $/ \mathrm{km}$ ), and high density (more than 0.5 colonies $/ \mathrm{km}$ ).

The estimation of the number of beavers in different classes of rivers in the region showed that most settlements fall on small and smallest rivers. 250 beaver settlements were registered in large rivers and 220 settlements were registered in average rivers. By extrapolation, it can be assumed that the number of settlements in medium rivers can be up to 300 . Small rivers accounted for 570 settlements. In small and smallest rivers, with a total length of $8,032 \mathrm{~km}$, the number of settlements can be up to 3,700 . Thus, the ratio of settlements in large, medium and small rivers is as follows: $6 \%, 7 \%$, and $87 \%$, respectively. The total number of settlements in the rivers of the region is 4,250 . Taking into account that, on average, there are 3-4 individuals per settlement, it is easy to determine the total number of beavers as 17,000 individuals only in rivers. Moreover, it is necessary to take into account that beavers live practically in every lake in the basin of the Sura and the Moksha, as well as in artificial ponds (ponds). Therefore, the number of beavers in all reservoirs in Mordovia will be even higher.

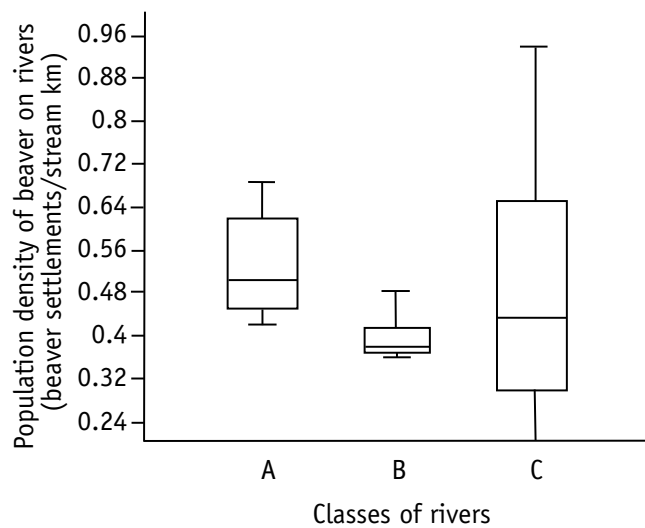

Figure 2. The variation range of Eurasian beaver population density on the region rivers. $A$ - big river $(n=3), B$ - average river ( $n$ $=5), C$ - small river $(n=33)$. Box plots indicate median (solid line), 25-75\% range (box) and the minimum and maximum values (whiskers).

\section{Discussion}

Literature includes a lot of guidance on the restoration size and density of the Eurasian beaver and the American beaver ( $C$. canadensis). There are reports that beavers were reduced in number at the site where they were cut off by moving to neighbouring areas (Bhat et al., 1993; DeStefano et al., 2006). This is evidenced by the number of beavers in different countries. A similar pattern was observed in the western rivers of Mordovia, in particular in the Vad, the Partsa, and the Vyndrey.

Somewhat lower numbers of beaver population density compared to the rivers 
of other countries were found particularly in the European rivers of Mordovia. It should lead to comparisons of the situation in some other regions. The density of beaver population in Newfoundland is 0.24 beaver colony sites $/ \mathrm{km}$ (Bergerud \& Miller, 1977).

Our data on the density of beaver settlements are consistent with the results of scientists from Norway, Sweden, and Finland (from 2.4 to 3.8 individuals in the settlement) (Parker et al., 2002; Rosell et al., 2006). The density of the American beaver population in Tierra del Fuego (TDF) (Argentina) is $0.2-5.8$ beaver colony sites $/ \mathrm{km}$ (Lizarralde, 1993). Between 1999 and 2001, the mean density of the beaver population in the Chilean part of TDF and the adjacent southern island Navarino (NAV) was 1.03 (range: 0.15-1.91) and 1.1 per $\mathrm{km}$ (Skewes et al., 2006).

Comparable results of counting can be led by counting areas of the American beavers in Allegany State Park and their vicinity in New York from 1984 to 1996, thus the density of the breeders was 45 to 64 pairs $x$ 2 / 250 (study area) $=0.36$ to 0.51 beavers / $\mathrm{km}^{2}$ (Sun et al., 2000)

In southwestern Sweden, according to an estimate calculated as the sum of all found colonies divided by the sum of all surveyed areas, the beaver population density of the whole province increased from 0.10 colonies $/ \mathrm{km}^{2}$ in 1976 to 0.19 colonies / $\mathrm{km}^{2}$ in 1987, and then levelled at 0.21 colonies $/ \mathrm{km}^{2}$ in 1999 (Hartman, 2003).

Our research has shown that in small rivers of the region, the conditions for beaver habitation are better in comparison with medium and large rivers. In the conditions of the continuing protection of the beaver population in Mordovia, it is possible to restore their abundance in the rivers where they were exterminated due to movements from neighbouring small rivers. The species from the Red Book cannot be excluded. In the future, it is necessary to conduct constant research on changes in the number of beavers in different river sections. The obtained data should be taken into account in the future with subsequent releases of beavers in different landscapes of Mordovia. They are important for environmental organisations in the region (Andreychev, 2012), as the restoration of water dwellers depends on the success of their activities. It is known that by restoring beaver populations, conditions for biodiversity are created and improved.

Acknowledgements. We are grateful to Alexandr Lapshin and Vyacheslav Kuznetsov for support in carrying out field studies, and Natalia Letkina for English proofreading.

\section{References}

Andreychev, A.V. 2012. Organization theriological Protected Areas in the Republic of Mordovia, the face. - Proceedings of the Dagestan State Pedagogical University, 4, 17-22. (In Russian).

Andreychev, A.V., Kuznetsov, V.A. 2012. Mammals of Mordovia. (Mlekopitayushchie Mordovii). Mordovia State University, Saransk. 100 pp. (In Russian).

Andreychev, A.V., Kuznetsov, V.A., Lapshin, A.S., Grishutkin, G.F. 2009. Status of the population eurasian beaver (Castor fiber L.) in Bolshebereznikovskii district in the Republic of Mordovia (on registration papers). Rare animals of the Republic of Mordovia: Material of maintenance of the Red Data Book of the Republic of Mordovia in 2009. Izdatelstvo Mordovskogo Universiteta, Saransk, p. 7-11. (In Russian).

Bergerud, A.T., Miller, D.R. 1977. Population dynamics of Newfoundland beaver. - Canadian Journal of Zoology, 55(9), 1480-1492.

Bhat, M.G., Huffaker, R.G., Lenhart, S.M. 1993. Controlling forest damage by dispersive beaver populations: Centralized optimal management strategy. - Ecological Applications, 3(3), 518-530.

Borodin, L.P. 1970. Russian desman in the flood plains of rivers Moksha and Sura. - Proceedings of the Mordovia State Nature Reserve, 5, 61-90. (In Russian).

Borodina, M.N. 1966. Materials for the study of dynamics of beaver populations Moksha. - Proceedings of the Mordovia State Nature Reserve, 3, 5-37. (In Russian).

Borodina, M.N., Borodin, L.P., Tereshkin, I.S., Shtarev, Y.F. 1970. Mammals Mordovia reserve. - Proceedings of the Mordovia State Nature Reserve, 5C, 5-60. (In Russian). 
Chalov, R.S. 1994. Of riverbed mode of the rivers of northern Eurasia. Izdatelstvo Moskovskogo Universiteta, Moscow. 336 pp. (In Russian).

DeStefano, S., Koenen, K.K.G., Henner, C.M., Strules, J. 2006. Transition to independence by subadult beavers (Castor canadensis) in an unexploited, exponentially growing population. - Journal of Zoology, 269, 434-441.

Dyakov Yu, V. 1975. Beavers European part of the Soviet Union. Moscow Worker, Moscow. 456 p. (In Russian).

Halley, D.J., Rosell, F. 2003. Population and distribution of European beavers (Castor fiber). - Lutra, 46(2), 91-101.

Hammer, Ø., Harper, D.A.T., Ryan, P.D. 2001. PAST: Paleontological statistics software package for education and data analysis. - Palaeontologia Electronica, 4(1), 9.

Hartman, G. 2003. Irruptive population development of European beaver (Castor fiber) in southwest Sweden. - Lutra, 46(2), 103-108.

Johnston, C.A., Naiman, R.J. 1990. Aquatic patch creation in relation to beaver population trends. Ecology, 71, 1617-1621.

Kolesnikov, V.V., Mashkin, V.V., Piminov, V.N., Andreev, M.N., Grevtsev, V.N., Ketova, N.S., Kozlovsky, I.S., Larionov, M.A., Pankratov, A.N., Sinitsyn, A.A., Skumatov, D.V., Solovyov, V.A., Sukhanov, M.S., Syshev, I.M., Utrobina, V.V., Ekonomov, A.V. 2011. Monitoring of hunting resources animals of Russia. Rabbit breeding and farming. - Rabbit Breeding, Fur Farming and Fur Business, 3, 30-32. (In Russian).

Lizarralde, M.S. 1993. Current status of the introduced beaver (Castor canadensis) population in Tierra del Fuego, Argentina. - Ambio, 22(6), 351-358.

Parker, H., Rosell, F., Hermansen, T.A., Sørløkk, G., Stærk, M. 2002. Sex and age composition of spring-hunted Eurasian beaver in Norway. - The
Journal of Wildlife Management, 66(4), 1164 1170.

Rosell, F., Bozser, O., Collen P., Parker, H. 2005. Ecological impact of beavers Castor fiber and Castor canadensis and their ability to modify ecosystems. - Mammal Review, 35(3-4), 248-276.

Rosell, F., Parker, H., Steifetten, Ø. 2006. Use of dawn and dusk sight observations to determine colony size and family composition in Eurasian beaver Castor fiber. - Acta Theriologica, 51(1), 107-112.

Skewes, O., Gonzalez, F., Olave, R., Avila, A., Vargas, V., Paulsen, P., Konig H.E. 2006. Abundance and distribution of American beaver, Castor canadensis (Kuhl 1820), in Tierra del Fuego and Navarino islands, Chile. - European Journal of Wildlife Research, 52(4), 292-296.

Sokolov, A.A. 1964. Hydrography of the USSR. Gidrometeoizdat, Leningrad. 468 pp. (In Russian).

Sokolovsky, D.A. 1968. River drain. Gidrometeoizdat, Leningrad. 539 pp. (In Russian).

Sosnina, M.V., Sosnin, V.Y., Andreychev, A.V. 2014. Results of census of eurasian beaver around the village Kaimar Krasnoslobodskii district in the Mordovia. Rare animals of the Republic of Mordovia: Material of maintenance of the Red Data Book of the Republic of Mordovia in 2009. Izdatelstvo Mordovskogo Universiteta, Saransk, p. 37-39. (In Russian).

Sun, L., Muller-Schwarze, D., Schulte, B.A. 2000. Dispersal pattern and effective population size of the beaver. - Canadian Journal of Zoology, 78, 393-398.

Water resources of Republic Mordovia and geo-ecological problems of their development. 1999. -Yamashkin, A.A., Safonov, V.N., Shutov, A.M. et al. (eds.). Saransk. 188 pp. (In Russian).

Yevstigneyev, V.M. 1990. River drain and hydrological calculations. Izdatelstvo Moskovskogo Universiteta, Moscow. 304 pp. (In Russian). 